\title{
Effect of precipitation on soil respiration in a temperate broad-leaved forest
}

\author{
Seok-Hee Jeong ${ }^{1}$, Ji-Young Eom', Joo-Yeon Park', Jung-Hwa Chun² and Jae-Seok Lee ${ }^{1 *}$ (D)
}

\begin{abstract}
Background: For understanding and evaluating a more realistic and accurate assessment of ecosystem carbon balance related with environmental change or difference, it is necessary to analyze the various interrelationships between soil respiration and environmental factors. However, the soil temperature is mainly used for gap filling and estimation of soil respiration (Rs) under environmental change. Under the fact that changes in precipitation patterns due to climate change are expected, the effects of soil moisture content (SMC) on soil respiration have not been well studied relative to soil temperature. In this study, we attempt to analyze relationship between precipitation and soil respiration in temperate deciduous broad-leaved forest for 2 years in Gwangneung.

Results: The average soil temperature (Ts) measured at a depth of $5 \mathrm{~cm}$ during the full study period was $12.0^{\circ} \mathrm{C}$. The minimum value for monthly Ts was $-0.4^{\circ} \mathrm{C}$ in February 2015 and $2.0^{\circ} \mathrm{C}$ in January 2016 . The maximum monthly Ts was $23.6^{\circ} \mathrm{C}$ in August in both years. In 2015, annual precipitation was $823.4 \mathrm{~mm}$ and it was $1003.8 \mathrm{~mm}$ in 2016 . The amount of precipitation increased by 21.9\% in 2016 compared to 2015, but in 2015, it rained for 8 days more than in 2016. In 2015, the pattern of low precipitation was continuously shown, and there was a long dry period as well as a period of concentrated precipitation in $2016.473 .7 \mathrm{~mm}$ of precipitation, which accounted for about $51.8 \%$ of the precipitation during study period, was concentrated during summer (June to August) in 2016. The maximum values of daily Rs in both years were observed on the day when precipitation of $20 \mathrm{~mm}$ or more. From this, the maximum Rs value in 2015 was $784.3 \mathrm{mg} \mathrm{CO}_{2} \mathrm{~m}^{-2} \mathrm{~h}^{-1}$ in July when $26.8 \mathrm{~mm}$ of daily precipitation was measured. The maximum was $913.6 \mathrm{mg} \mathrm{CO}_{2} \mathrm{~m}^{-2} \mathrm{~h}^{-1}$ in August in 2016, when $23.8 \mathrm{~mm}$ of daily precipitation was measured. Rs on a rainy day was 1.5 1.6 times higher than it without precipitation. Consequently, the annual Rs in 2016 was about 12\% higher than it was in 2015. It was shown a result of a 14\% increase in summer precipitation from 2015.

Conclusions: In this study, it was concluded that the precipitation pattern has a great effect on soil respiration. We confirmed that short-term but intense precipitation suppressed soil respiration due to a rapid increase in soil moisture, while sustained and adequate precipitation activated Rs. In especially, it is very important role on Rs in potential activating period such as summer high temperature season. Therefore, the accuracy of the calculated values by functional equation can be improved by considering the precipitation in addition to the soil temperature applied as the main factor for long-term prediction of soil respiration. In addition to this, we believe that the accuracy can be further improved by introducing an estimation equation based on seasonal temperature and soil moisture.
\end{abstract}

Keywords: Soil respiration, Soil temperature, Soil moisture content, Automatic open/closed chamber system, Monsoon climate

\footnotetext{
* Correspondence: jaeseok@konkuk.ac.kr

${ }^{1}$ Department of Biological science, Konkuk Universtiy, Seoul, South Korea

Full list of author information is available at the end of the article
}

(c) The Author(s). 2018 Open Access This article is distributed under the terms of the Creative Commons Attribution 4.0 International License (http://creativecommons.org/licenses/by/4.0/), which permits unrestricted use, distribution, and reproduction in any medium, provided you give appropriate credit to the original author(s) and the source, provide a link to the Creative Commons license, and indicate if changes were made. The Creative Commons Public Domain Dedication waiver (http://creativecommons.org/publicdomain/zero/1.0/) applies to the data made available in this article, unless otherwise stated. 


\section{Background}

Soil contains about twice as much carbon as that stored in the atmosphere; therefore, soil carbon flux can have a significant impact on the global ecosystem carbon cycle even if the changes are small (Oikawa 1991; Post et al. 1982; Lee et al. 2017). In addition, many predictions suggest that soil respiration will increase with increasing temperature due to global warming and loss of $\mathrm{CO}_{2}$ in the soil will cause positive feedback that further enhances global warming (Raich and Schlesinger 1992; Rustad et al. 2000; Schimel 1995; Woodwell et al. 1998). Therefore, quantifying soil respiration (Rs) has become the first task towards predicting changes in atmospheric $\mathrm{CO}_{2}$ concentration in the future (Hirano et al. 2003). Thus, many research groups have collected soil respiration data in various environments and tried to analyze the relationship between soil respiration and the environmental factors that affect soil respiration to predict change in the global carbon cycle.

In general, soil respiration is the result of autotrophic and heterotrophic respiration (Fang et al. 1998; Hanson et al. 2000), which mainly depends on soil temperature and soil moisture content (Aerts 1997; Meentemeyer 1984; Eom et al. 2018; Jeong et al. 2018). In many studies, soil temperature is the best predictor of soil respiration when using exponential functions (Lloyd and Taylor 1994; Raich and Schlesinger 1992; Rayment and Jarvis 2000; Xu and Qi 2001). However, although soil moisture content is an important environmental factor in ecosystem carbon cycles, the correlation between soil moisture and soil respiration differs among studies, and some studies suggest that soil moisture content is passive in reflecting future soil carbon emission (Davidson et al. 2000; Liang et al. 2004; Mo et al. 2005; Wu et al. 2006); however, other studies have indicated that the change in precipitation in the monsoon climate regions is one of the phenomena caused by climate change and predict that precipitation in Korea will be more severe during the rainy season (Kwon et al. 2009; Yun et al. 2008). Indeed, the effects of soil temperature on soil respiration may be limited by precipitation characteristics during summer in the Asian monsoon regions that provide a rich water environment for soil respiration (Lee et al. 2002; Lee et al. 2008; Lee et al. 2010; Yuste et al. 2003; Jeong et al. 2017; Jeong et al. 2018). In addition, the soil moisture content, which largely depends on precipitation, is sensitive to changes in precipitation patterns and precipitation intensity. Change in soil moisture content due to precipitation is expected to cause changes in soil respiration and carbon balance (Dairaku et al. 2004). Therefore, it is necessary to analyze the interrelationships between precipitation, soil moisture, and soil respiration; in addition, understanding the characteristics of soil carbon flux will be a more realistic and accurate assessment of ecosystem carbon balance (Chae 2011). Consequently, for a realistic prediction of the carbon cycle, soil respiration data that reflects various environmental factors such as precipitation effect should be collected (Kim et al. 2010).

The data from previous studies that analyzed the linkage between soil respiration, precipitation, and soil moisture are irregular and rough data, and the complexity of precipitation effects on the ecosystem carbon cycle remains uncertain (Dairaku et al. 2004; Yuste et al. 2003; Zhou et al. 2009). This is because the manual and temporal measurement of soil respiration during precipitation is a very difficult task, and it is usually measured discontinuously on a clear day, before or after a precipitation, once or twice a month. As a result, detailed data that are required for the analysis of soil respiration affected by precipitation is limited and only data focused on temperate conditions exists (Kim et al. 2010; Lee et al. 2010; Lin et al. 1999; Noh et al. 2010). Therefore, there is no sufficient basic data to analyze the response of soil respiration to soil moisture, and there is a limitation in using soil moisture as a parameter for predicting soil carbon emission. For a more precise prediction of future carbon cycles, data on the response of soil respiration to soil moisture in various ecosystems and the relationship between these two factors should be defined.

In this study, soil moisture content and soil respiration data were collected from a temperate broad-leaved forest in Korea using the automatic open/closed chamber system that can measure continuous soil respiration under various environmental conditions, including rainfall. With these data, we tried to understand the effect of soil moisture content on soil respiration due to precipitation.

\section{Methods \\ Study site}

The study was conducted in a natural temperate deciduous forest located on the west-central part in the Korean Peninsula $\left(37^{\circ} 45^{\prime} 25.37^{\prime \prime} \mathrm{N}, 127^{\circ} 09^{\prime} 11.62^{\prime \prime} \mathrm{E} ; 340 \mathrm{~m}\right.$ above mean sea level). The stand is predominantly composed of Quercus serrata, Carpinus laxiflora, and Capinus cordata. In addition, since the study site is under strict protection, it has limited artificial disturbance and minimal environmental changes due to human activity. Therefore, this site was the most appropriate place to measure changes in soil respiration and environmental factors that affect Rs in forest ecosystems in temperate monsoon climate regions.

\section{Environmental factors}

Soil temperature (Ts) primarily affects Rs. The Ts was measured at a $5 \mathrm{~cm}$ depth with a thermocouple (T-CC, $0.32 \mathrm{~mm}$, Ninomiya) located near the chamber used to measure Rs. Soil moisture content (SMC) was also 
measured near the chamber at a $15 \mathrm{~cm}$ depth using CS616 (Campbell Scientific Inc., Logan, Utah, USA). Both Ts and SMC were measured at the same time, and the averages was calculated every $30 \mathrm{~s}$ and recorded every $2 \mathrm{~min}$ in a data logger (CR10X, Campbell Scientific Inc., Logan, Utah, USA). Precipitation directly affects the SMC and was therefore recorded by connecting a rain gauge (S-RGB-M002, Onset, MA, USA) to the upper part of the forest canopy and connecting a 30-min unit accumulation amount to a data logger (HOBO micro station, Onset, MA, USA). All sensors were measured between January 2015 and December 2016.

\section{Soil respiration (Rs)}

To measure Rs, an automatic open/closed chamber (AOCC) system with six chambers was installed in the study area and Rs was continuously measured from 2015 to 2016. The chambers closed for $10 \mathrm{~min}$ automatically per chamber, and the air in the system was circulated in the infrared gas analyzer (IRGA; LI-820, Li-Cor, Lincoln, Nebraska, USA) by a pump to measure $\mathrm{CO}_{2}$. Rs was calculated from the rate of increase in $\mathrm{CO}_{2}$ concentration measured per unit of time (Eq. 1). It was possible to obtain continuous and high-resolution data on Rs changes caused by precipitation (Suh et al. 2006) using the AOCC system. A detailed description of this type of system can be found in Suh et al. (2006). The Rs was defined as:

$$
\operatorname{Rs}=(a \cdot V \cdot \rho) / A
$$

where $a\left(\Delta \mathrm{CO}_{2} / \Delta \mathrm{t}\right)$ is the rate of change of the $\mathrm{CO}_{2}$ concentration in the chamber, $V$ is the volume of the chamber, $\rho$ is the density of $\mathrm{CO}_{2}$, and $A$ is the surface area of the chamber.

\section{Results and discussion \\ Soil temperature}

The average Ta was $12.7^{\circ} \mathrm{C}$ in the broad-leaved forest study site during the study period. And Ta rose about $0.1{ }^{\circ} \mathrm{C}$ in 2016 compared to 2015 (Fig. 1). The average Ta in early spring to summer in 2016 was $1.2^{\circ} \mathrm{C}$ higher than the average in 2015. Monthly Ta measurements showed typical seasonal changes in both years. The lowest Ta was observed in January, and the average was $-2.4{ }^{\circ} \mathrm{C}$. The Ta then rose steadily and then increased in earnest in April. In both years, the highest Ta was recorded as $25.0{ }^{\circ} \mathrm{C}$ in August, and steadily decreased to $1.4{ }^{\circ} \mathrm{C}$ in December.

The average Ts measured at a depth of $5 \mathrm{~cm}$ from the soil surface during the entire study period was $12.0{ }^{\circ} \mathrm{C}$, which was $0.7^{\circ} \mathrm{C}$ lower than $\mathrm{Ta}$ and showed an annual variation similar to Ta. Compared to 2015, the annual Ts rose by $1.1{ }^{\circ} \mathrm{C}$ in 2016 . Ts measurements in early spring to summer in 2016 were $2.4{ }^{\circ} \mathrm{C}$ higher than those in 2015 because of increased Ta. The warmer temperature at this time caused the longer growing season because of earlier germination of plants (Ito 2008). The minimum value for monthly Ts was $-0.4{ }^{\circ} \mathrm{C}$ in February 2015 and $2.0{ }^{\circ} \mathrm{C}$ in January 2016. However, the maximum average value for monthly Ts was $23.6{ }^{\circ} \mathrm{C}$ in August in both years. Seasonal change in Ts was almost the same as Ta, but the fluctuation in Ts was lower than that in Ta (Fig. 1).

\section{Precipitation and soil moisture content}

The annual precipitation in the study site was measured to be $913.6 \mathrm{~mm}$ on average. In 2015, annual precipitation

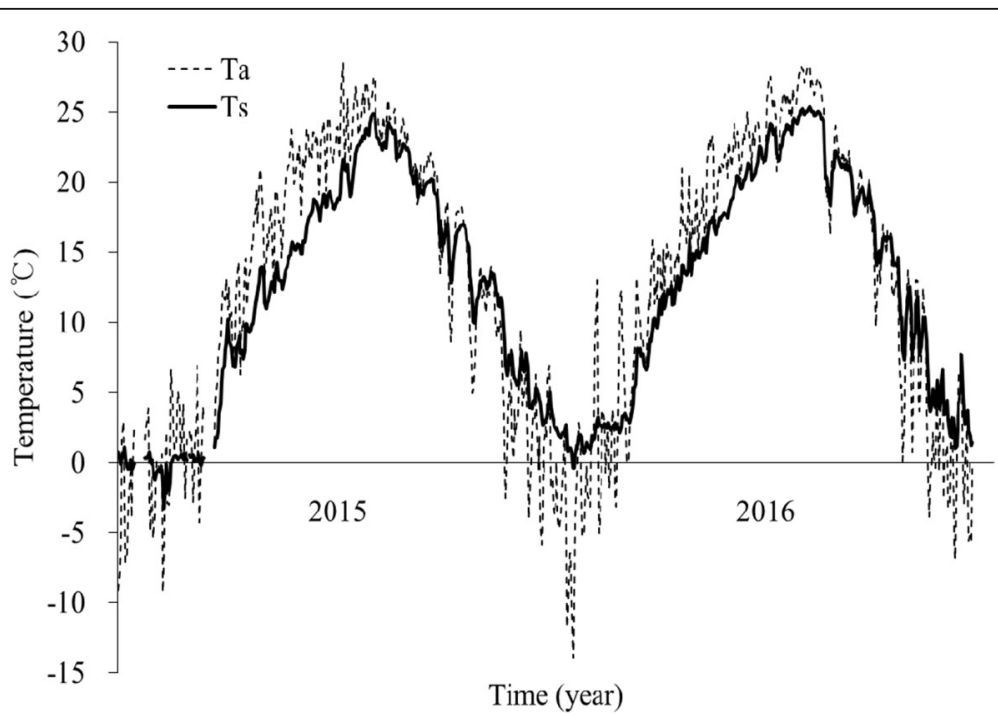

Fig. 1 Variation in daily air temperature (Ta) and soil temperature (Ts) measured at a $5 \mathrm{~cm}$ depth in a temperate broad-leaved forest in Korea. Both temperatures were higher in 2016 than in 2015 
was $823.4 \mathrm{~mm}$ and in 2016 it was $1003.8 \mathrm{~mm}$ (Fig. 2).The amount of precipitation increased by $21.9 \%$ in 2016 compared to 2015, but in 2015, it rained for 8 days more than in 2016.In addition, in 2015, the pattern of low precipitation was continuously measured, and in 2016, there was a long dry period as well as a period of concentrated precipitation. In both years, monthly precipitation of less than $45 \mathrm{~mm}$ was recorded between January and March, and precipitation increased to more than $75 \mathrm{~mm}$, in April when the temperature increased. Indeed, $473.7 \mathrm{~mm}$ of precipitation, which accounted for about $51.8 \%$ of the average precipitation during study period, was concentrated during summer (June to August) in the monsoon climate. These measurements are consistent with previous work that has shown that summer precipitation accounts for about half of the annual precipitation in the Asian monsoon climate region (Jung et al. 2013; Laiju et al. 2012). Other seasonal precipitation rates were $8.9 \%$ in winter, $16.9 \%$ in autumn, and $22.4 \%$ in spring.

The average SMC was $21.2 \%$ in 2015 and $21.3 \%$ in 2016, and the annual average was $21.3 \%$ (Fig. 2). In the early spring, the amount of precipitation was very low, but SMC increased due to the thawing of snow melt from during winter and the limited water evaporation from the litter layer that accumulated over the year
(Wang et al. 2006). SMC remained high due to the increased precipitation in April, but decreased again in early summer when the rainy season did not begin. This event was potentially caused by precipitation trapped by the canopy during the growing season; the water could have evaporated due to the sudden rise in temperature at the start of the spring season. The maximum value of SMC was measured in July-August in the rainy season, and from September, SMC decreased as the region entered the drier fall and winter seasons (Fig. 2). In addition, the minimum precipitation caused an increase in soil moisture in spring (1.7 $\mathrm{mm}$ on average) in both study years. And the minimum precipitation caused an increase in soil moisture was $5.9 \mathrm{~mm}$ in summer and $3.1 \mathrm{~mm}$ in autumn. In spring, the canopy is not yet developed and litter on the forest floor was thick from the last year had not decomposed due to the low temperature. Therefore, it is possible for soil moisture to change even under low precipitation. In summer, when the litter layer has decomposed and the canopy had developed, more precipitation is required to increase soil moisture than in spring because the canopy traps precipitation. In autumn, when the canopy is maintained and the litter layer is thin, precipitation entering the forest through the canopy immediately enters the soil;
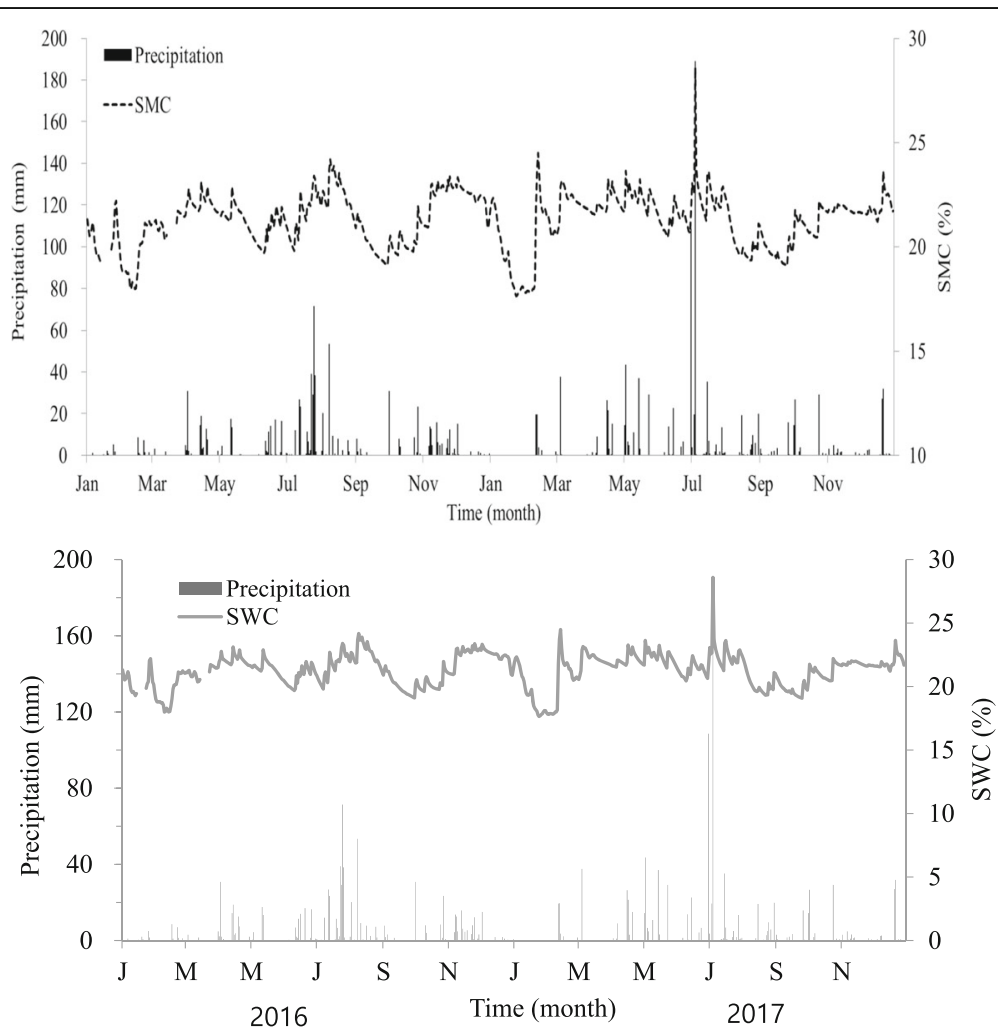

Fig. 2 Variation of daily precipitation and soil moisture content (SMC) measured at a $15 \mathrm{~cm}$ depth in a temperate broad-leaved forest from 2015 to 2016 . The amount of precipitation increased by $21.9 \%$ in 2016 compared to 2015 . And fluctuation in SMC was significantly larger in 2016 than in 2015 
therefore, a smaller amount of precipitation is required for increasing soil moisture than in summer. We observed that when the precipitation over the minimum precipitation was measured, the higher the precipitation levels were, the higher the SMC was regardless of the season.

The daily minimum SMC in 2015 was $18.0 \%$ in February, which was due to a dry period of 14 days and potentially also to freezing of soil moisture at subzero Ts. The daily maximum SMC in 2015 was $24.2 \%$ in August. It was considered that the precipitation effect of $53.4 \mathrm{~mm}$ on SMC was continued until the next day. In addition, the minimum value of daily SMC in 2016 was $17.6 \%$ in January because there was no rain during a month. The daily maximum in 2016 was $28.6 \%$ in July when there was intense precipitation each day (188.8 $\mathrm{mm}$ per day) during the rainy season. Fluctuation in SMC was significantly larger in 2016 than in 2015, which is attributed to precipitation patterns during the long dry period in and the concentrated precipitation in 2016. Both years also showed the general seasonal variation in which the minimum value of SMC was recorded in winter and the maximum was recorded in summer by the rainy season (Jung et al. 2013).

The annual precipitation in the study site was measured to be $913.6 \mathrm{~mm}$ on average. In 2015, annual precipitation was $823.4 \mathrm{~mm}$ and it was $1003.8 \mathrm{~mm}$ in 2016 . The amount of precipitation increased by $21.9 \%$ in 2016 compared to 2015, but in 2015, it rained for 8 days more than in 2016. In addition, in 2015, the pattern of low precipitation was continuously measured, and in 2016, there was a long dry period as well as a period of highly concentrated precipitation (Fig. 2). Indeed, about $51.8 \%$ of the average precipitation during study period was concentrated during summer (June to August). Other seasonal precipitation rates were $8.9 \%$ in winter, $16.9 \%$ in autumn, and $22.4 \%$ in spring.

The average SMC was $21.2 \%$ in 2015 and $21.3 \%$ in 2016 , and the annual average was $21.3 \%$. The daily maximum SMC in 2015 was $24.2 \%$ in August (Fig. 2). It was considered that the precipitation effect of $53.4 \mathrm{~mm}$ on SMC was continued until the next day. In addition, the minimum value of daily SMC in 2016 was $17.6 \%$ in January because there was no rain during a month. The daily maximum in 2016 was $28.6 \%$ in July when there was intense precipitation each day (188.8 $\mathrm{mm}$ per day) during the rainy season. Fluctuation in SMC was significantly larger in 2016 than in 2015, which is attributed to the long dry period in and the concentrated precipitation in 2016.

\section{Soil respiration and precipitation}

The annual Rs was estimated to be approximately $224.5 \mathrm{mgCO}_{2} \mathrm{~m}^{-2} \mathrm{~h}^{-1}$ in 2015 and $251.3 \mathrm{mgCO}_{2} \mathrm{~m}^{-2} \mathrm{~h}^{-1}$ in 2016. The annual Rs in 2016 was approximately $12 \%$ higher than in 2015 (Fig. 3). Although Ts has more of an impact on seasonal changes in Rs than SMC, moisture conditions in forests may limit the temperature response of soil $\mathrm{CO}_{2}$ emission and cause annual fluctuations in Rs (Joo et al. 2012). Thus, the annual Rs increase observed in 2016 was hypothesized to be a result of the $14 \%$ increase in summer precipitation in that year compared to 2015. In addition, Rs on a rainy day was 1.5-1.6 times higher than Rs on the day without precipitation. These results indicate that the seasonal characteristics of Rs are controlled by Ts and its characteristics on a short-term scale are regulated by water conditions (Joo et al. 2012).

The minimum daily $\mathrm{Rs}$ value in 2015 was $22.1 \mathrm{mg}$ $\mathrm{CO}_{2} \mathrm{~m}^{-2} \mathrm{~h}^{-1}$ in February when the maximum value of SMC was recorded, and the maximum Rs value was $784.3 \mathrm{mg} \mathrm{CO}_{2} \mathrm{~m}^{-2} \mathrm{~h}^{-1}$ in July when $26.8 \mathrm{~mm}$ of precipitation was measured. The minimum value of daily $\mathrm{Rs}$ in 2016 was $21.2 \mathrm{mg} \mathrm{CO}_{2} \mathrm{~m}^{-2} \mathrm{~h}^{-1}$ in early February, before the first precipitation was recorded in 2016, and the maximum was $913.6 \mathrm{mg} \mathrm{CO}_{2} \mathrm{~m}^{-2} \mathrm{~h}^{-1}$ in August, when $23.8 \mathrm{~mm}$ of daily precipitation was measured. The maximum values of daily Rs in both years were observed on the day when precipitation of $20 \mathrm{~mm}$ or more. The minimum values of daily SMC and Rs were measured at similar times, while the maximum values were not observed under similar conditions. Our data suggest that this may be a result of the difference in the level of precipitation. Daily precipitation was greater than $50 \mathrm{~mm}$ when the maximum SMC appeared, leading to a sharp increase in SMC but a gradual increase of decrease in Rs. However, on the day with maximum Rs, daily precipitation was less than $30 \mathrm{~mm}$, resulting in a gradual increase in SMC and a gradual or sharp increase in Rs. A short-term, intense period of precipitation causes a drastic increase in SMC, and as a result, the rate of gas diffusion in the soil pore decreases and the production of $\mathrm{CO}_{2}$ by organic matter decomposition is suppressed (Linn and Doran 1984). However, the proper hydration of soil positively affects roots and microbial activity, which activates Rs (Davidson et al. 1998; Liu et al. 2002; Raich and Schlesinger 1992).

Previous studies have shown that soil $\mathrm{CO}_{2}$ emission rapidly increases when dry soil is rewetted (Birch 1958; Pumpanen et al. 2003; Van Gestel et al. 1991). In the present study, Rs immediately increased by $10.9 \mathrm{mg} \mathrm{CO}_{2}$ $\mathrm{m}^{-2} \mathrm{~h}^{-1}$ up to $137.2 \mathrm{mg} \mathrm{CO} \mathrm{CO}_{2} \mathrm{~m}^{-2} \mathrm{~h}^{-1}$ after more than $5 \mathrm{~mm}$ of daily precipitation when the region had gone without rain for more than 7 days. However, the sustained responses of Rs were reversed between 2015 and 2016. In the case of a single rainy day after a long drought in 2015, both SMC and Rs decreased immediately during the following day. With continuous precipitation that lasted more than 2 days, both soil moisture and Rs increased until the next day and then decreased 


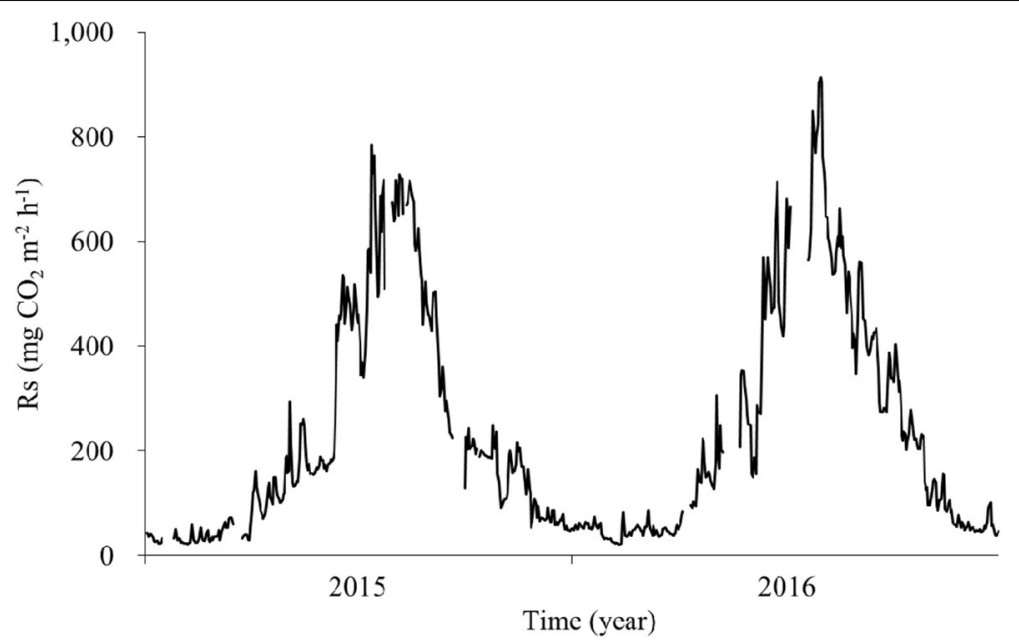

Fig. 3 Variation of daily soil respiration (Rs) measured in a temperate broad-leaved forest in Korea from 2015 to 2016. The annual Rs in 2016 was approximately $12 \%$ higher than in 2015

after 2 days. However, during a single day of precipitation in 2016, both SMC and Rs continued to increase until the next day, similar to what has been observed during continuous precipitation in 2015. During instances of continuous precipitation in 2016, both SMC and Rs decreased immediately after the next day, similar to observations made on days with a single precipitation event in 2015 and are thought to be the result of a change in the precipitation pattern. In 2015, the cumulative precipitation of less than $15 \mathrm{~mm}$ was measured over an average of 4 days and the cumulative precipitation in 2016 was more than $20 \mathrm{~mm}$ over 2 days. In addition, a single precipitation event in 2015 was less than $10 \mathrm{~mm}$ averaged over 20 days, and a single precipitation event in 2016 was more than $20 \mathrm{~mm}$ averaged over 10 days. These results suggest that short-term intense precipitation suppresses Rs due to a rapid increase in soil moisture, and that continuous and proper amounts of precipitation activate Rs (Davidson et al. 1998; Linn and Doran 1984; Liu et al. 2002; Raich and Schlesinger 1992).

In addition, during summer (June to August), when precipitation was concentrated and the hourly precipitation was $4.6 \mathrm{~mm}$ or more, soil moisture and Rs increased immediately after the precipitation event (Fig. 4a). SMC

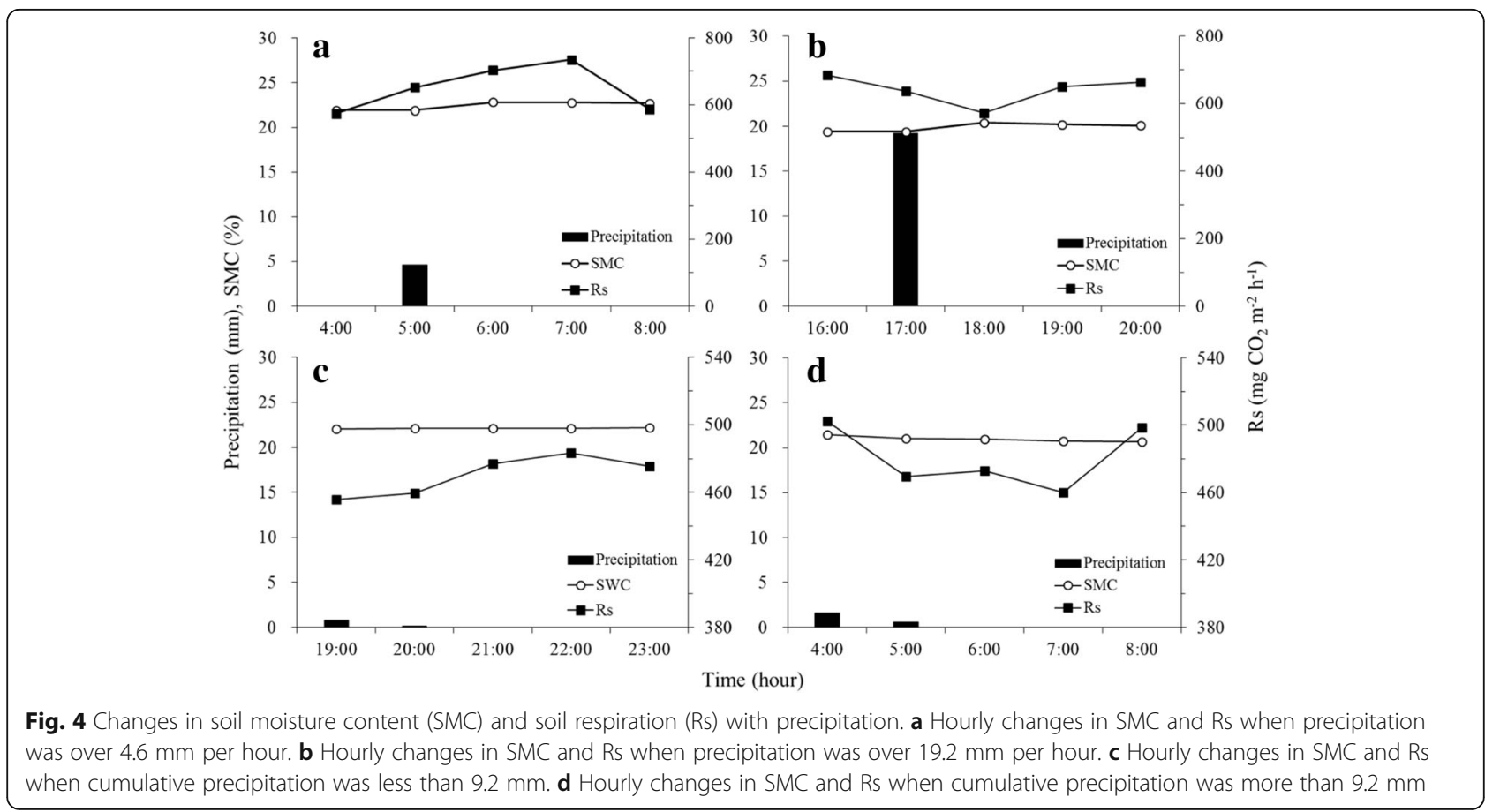


increased by $2.0 \%$ immediately after precipitation and Rs also increased by $241.6 \mathrm{mg} \mathrm{CO} \mathrm{m}^{-2} \mathrm{~h}^{-1}$. These increases persisted up to $2 \mathrm{~h}$ afterward precipitation ended, and then returned to its previous level. However, when hourly precipitation was more than $19.2 \mathrm{~mm}, \mathrm{SMC}$ increased and Rs decreased (Fig. 4b). SMC increased until $1 \mathrm{~h}$ after precipitation and then began to decrease. Rs decreased until $1 \mathrm{~h}$ after the precipitation and then began to increase again. In addition, when a small amount of precipitation of less than $4 \mathrm{~mm}$ per $\mathrm{h}$ persisted and the cumulative precipitation was less than $9.2 \mathrm{~mm}$, we observed an increase in SMC and Rs to measurements taken before the precipitation event (Fig. 4c). SMC increased by $2.1 \%$ and Rs increased by $211.3 \mathrm{mg} \mathrm{CO} \mathrm{m}^{-2} \mathrm{~h}^{-1}$. It was observed that both SMC and Rs continued to increase for up to $2 \mathrm{~h}$ immediately after the precipitation event, and thereafter, both factors decreased. However, when the cumulative precipitation exceeded $9.2 \mathrm{~mm}$, SMC increased and Rs decreased after the precipitation event compared to before the start of precipitation (Fig. 4d). Furthermore, immediately after precipitation, SMC increased by $1.7 \%$ and Rs was decreased by $100.4 \mathrm{mg} \mathrm{CO}_{2} \mathrm{~m}^{-2} \mathrm{~h}^{-1}$ compared to before the start of the precipitation event. These responses lasted for $2 \mathrm{~h}$ after precipitation ended and then returned to their previous levels. In the present study, continuous measurements were performed under severe weather conditions using the AOCC system and the effect of precipitation on Rs lasted up to $2 \mathrm{~h}$; however, in the case of the previous non-continuous studies that measured Rs every 2 weeks or once a month, it was not possible to measure the immediate change in soil $\mathrm{CO}_{2}$ emissions that were due to precipitation. Consequently, previous results from the literature (Kim et al. 2010) may be different from the natural conditions.

\section{Conclusions}

The annual soil respiration in 2016 was 12\% higher than that measured in 2015 using an automatic open/closed chamber system in a Korean temperate broad-leaved forest. The annual soil respiration increased in 2016 and was hypothesized to be a result of a $14 \%$ increase in summer precipitation compared to 2015. Consequentially, we confirmed that short-term intense precipitation suppressed soil respiration due to a rapid increase in soil moisture, compared to sustained and adequate precipitation, which activated soil respiration.

We determined that this was caused by changes in soil moisture due to changes in precipitation and analyzed the seasonal relationship between soil respiration and soil moisture content. In this study, the correlation between these two factors in summer with activate soil respiration and winter was higher than in the spring and autumn seasons. Therefore, for soil respiration to be used as a parameter for predicting soil carbon emissions, the influence of precipitation and soil moisture content on soil respiration should be analyzed by season to reflect the various environmental changes that affect the interrelationships between these factors. In especially, precipitation in summer season has to be considered one of the major important factors.

\section{Abbreviations \\ AOCC: Automatic open/closed chamber; Rs: Soil respiration; SMC: Soil moisture content; Ta: Air temperature; Ts: Soil temperature}

\section{Acknowledgements}

This work is based on the research project, "Long-term Ecological Research on Forests," which was conducted at the National Institute of Forest Science (NIFoS), Korea.

\section{Funding}

This study received funding from the National Institute of Forest Science (NIFOS).

\section{Authors' contributions}

All authors contributed in the manuscript. JSH has mainly constructed and installed an field measurement system. EJY wrote the method and result parts in the manuscript. JHC analyzed the field row data. PJY provided a role in the preparation of field surveys and management of collected row data. LS participated in the system maintenance, management of the experimental site, and the analysis of measurement data. All authors confirmed and agreed to describe the role of the paper and the author list of the paper.

\section{Ethics approval and consent to participate}

Not applicable.

Competing interests

The authors declare that they have no competing interests.

\section{Publisher's Note}

Springer Nature remains neutral with regard to jurisdictional claims in published maps and institutional affiliations.

\section{Author details}

${ }^{1}$ Department of Biological science, Konkuk Universtiy, Seoul, South Korea. ${ }^{2}$ Division of Forest Ecology, National Institute of Forest Science (NIFoS), Seoul, South Korea.

Received: 28 November 2017 Accepted: 4 June 2018

Published online: 15 June 2018

\section{References}

Aerts, R. (1997). Climate, leaf litter chemistry and decomposition in terrestrial ecosystems: a triangular relationship. Oikos, 79, 439-449.

Birch, H. F. (1958). The effect of soil drying on humus decomposition and nitrogen availability. Plant and Soil, 10, 9-31.

Chae, N. Y. (2011). Annual variation of soil respiration and precipitation in a temperate forest (Quercus serrata and Carpinus laxiflora) under East Asian monsoon climate. Journal of Plant Biology, 54, 101-111.

Dairaku, K., Emori, S., \& Oki, T. (2004). Rainfall amount, intensity, duration and frequency relationships in the Mae Chaem Watershed in Southeast Asia. Journal of Hydrometeorology, 5, 458-470.

Davidson, E. A., Belk, E., \& Boone, R. D. (1998). Soil water content and temperature as independent or confounded factors controlling soil respiration in a temperate mixed hardwood forest. Global Change Biology, 4, 217-227.

Davidson, E. A., Verchot, L. V., Cattaanio, J. H., Ackerman, I. L., \& Carvalho, J. E. M. (2000). Effects of soil water content on soil respiration in forests and cattle pastures of eastern Amazonia. Biogeochemistry, 48, 53-69.

Eom, J. Y., Jeong, S. H., Chun, J. H., Lee, J. H., \& Lee, J. S. (2018). Long-term characteristics of soil respiration in a Korean cool-temperate deciduous forest in a monsoon climate. Animal Cells and Systems. https://doi.org/10.1080/ 19768354.2018.1433234. 
Fang, C., Moncrieff, J. B., Gholz, H. L., \& Clark, K. L. (1998). Soil CO 2 efflux and its spatial variation in a Florida slash pine plantation. Plant and Soil, 205, 135-146

Hanson, P. J., Eswards, C. T., Garten, C. T., \& Andrews, J. A. (2000). Separating root and soil microbial contributions to soil respiration: a review of methods and observations. Biogeochemistry, 48, 115-146.

Hirano, T., Kim, H., \& Tanaka, Y. (2003). Long-term half-hourly measurement of soil $\mathrm{CO}_{2}$ concentration and soil respiration in a temperate deciduous forest. Journal of Geophysical Research: Atmospheres, 108, D20.

Ito, A. (2008). The regional carbon budget of East Asia simulated with a terrestrial ecosystem model and validated using AsiaFlux data. Agricultural and Forest Meteorology, 148, 738-747

Jeong, S. H., Eom, J. Y., Lee, J. H. \& Lee, J. S. (2017). Effect of rainfall events on soil carbon flux in mountain pastures. Journal of Ecology and Environment, 41, 37

Jeong, S. H., Eom, J. Y., Park, J. Y., Lee, J. H. \& Lee, J. S. (2018). Characteristics of accumulated soil carbon and soil respiration in temperate deciduous forest and alpine pastureland. Journal of Ecology and Environment, 42, 3 .

Joo, S. J., Park, S. U., Park, M. S., \& Lee, C. S. (2012). Estimation of soil respiration using automated chamber systems in an oak (Quercus mongolica) forest at the Nam-San site in Seoul, Korea. Science of the Total Environment, 416, 400-409.

Jung, E. Y., Otieno, D., Kwon, H., Lee, B., Lim, J. H., Kim, J., \& Tenhunen, J. (2013). Water use by a warm-temperate deciduous forest under the influence of the Asian monsoon: contributions of the overstory and understory to forest water use. Journal of Plant Research, 126, 661-674.

Kim, D. G., Mu, S., Kang, S., \& Lee, D. (2010). Factors controlling soil $\mathrm{CO}_{2}$ effluxes and the effects of rewetting on effluxes in adjacent deciduous, coniferous, and mixed forests in Korea. Soil Biology and Biochemistry, 42, 576-585.

Kwon, H., Kim, J., \& Hong, J. (2009). Influence of the Asian Monsoon on net ecosystem carbon exchange in two major plant functional types in Korea. Biogeosciences Discussions, 6, 10279-10309.

Laiju, N., Otieno, D., Jung, E. Y., Lee, B., Tenhunen, J., Lim, J. H., \& Kang, S. (2012). Environmental controls on growing-season sap flow density of Quercus serrata Thunb in a temperate deciduous forest of Korea. Journal of Ecology and Environment, 35, 213-225.

Lee, J. H., Eom, J. Y., Jeong, S. H., Hong, S. B., Park, E. J., \& Lee, J. S. (2017). Influence of carbonized crop residue on soil carbon storage in red pepper field. Journal of Ecology and Environment, 41, 40.

Lee, M. S., Lee, J., \& Koizumi, H. (2008). Temporal variation in $\mathrm{CO}_{2}$ efflux from soil and snow surfaces in a Japanese cedar (Cryptomeria japonica) plantation, central Japan. Ecological Research, 23, 777-785.

Lee, M. S., Nakane, K., Nakatsubo, T., Mo, W. H., \& Koizumi, H. (2002). Effects of rainfall events on soil $\mathrm{CO}_{2}$ flux in a cool temperate deciduous broad-leaved forest. Ecological Research, 17, 401-409.

Lee, N. Y., Koo, J. W., Noh, N. J., Kim, J., \& Son, Y. (2010). Seasonal variation in soil $\mathrm{CO}_{2}$ efflux in evergreen coniferous and broad-leaved deciduous forests in a cool-temperate forest, central Korea. Ecological Research, 25, 609-617.

Liang, N., Nakadai, T., Hirano, T., Qu, L., Koike, T., Fujinuma, Y., \& Inoue, G. (2004). In situ comparison of four approaches to estimating soil $\mathrm{CO}_{2}$ efflux in a northern larch (Larix kaempferi Sarg.) forest. Agricultural and Forest Meteorology, 123, 97-117.

Lin, G., Ehleringer, J. R., Rygiewicz, P. T., Johnson, M. G., \& Tingey, D. T. (1999). Elevated $\mathrm{CO}_{2}$ and temperature impacts on different components of soil $\mathrm{CO} 1$ efflux in Douglas-fir terracosms. Global Change Biology, 5, 157-168.

Linn, D. M., \& Doran, J. W. (1984). Effect of water-filled pore space on carbon dioxide and nitrous oxide production in tilled and nontilled soils. Soil Science Society of America Journal, 48, 1267-1272.

Liu, X., Wan, S., Su, B., Hui, D., \& Luo, Y. (2002). Response of soil $\mathrm{CO}_{2}$ efflux to water manipulation in a tallgrass prairie ecosystems. Plant and Soil, 240, 213-223.

Lloyd, J., \& Taylor, J. A. (1994). On the temperature dependence of soil respiration. Functional Ecology, 8, 315-323.

Meentemeyer, V. (1984). The geography of organic decomposition rates. Annual Association of American Geography, 74, 551-560.

Mo, W., Lee, M. S., Uchida, M., Inatomi, M., Saigusa, N., Mariko, S., \& Koizumi, H. (2005). Seasonal and annual variations in soil respiration in a cool-temperate deciduous broad-leaved forest in Japan. Agricultural and Forest Meteorology, $134,81-94$

Noh, N. J., Son, Y., Lee, S. K., Yoon, T. K., Seo, K. W., Kim, C., Lee, W. K., Bae, S. W., \& Hwang, J. (2010). Influence of stand density on soil $\mathrm{CO}_{2}$ efflux for a Pinus densiflora forest in Korea. Journal of Plant Research, 123, 411-419.
Oikawa, T. (1991). Increase of atmospheric $\mathrm{CO}_{2}$ concentration and biosphere. Journal of Agricultural Meteorology, 47, 191-194.

Post, W. M., Emanuel, W. R., Zinke, P. J., \& Stangenberger, A. G. (1982). Soil carbon pools and world life zones. Nature, 298, 156-159.

Pumpanen, J., Ilvesniemi, H., Peramaki, M., \& Hari, P. (2003). Seasonal patterns of soil $\mathrm{CO}_{2}$ efflux and soil air $\mathrm{CO}_{2}$ concentration in a Scots pine forest: Comparison of two chamber techniques. Global Change Biology, 9, 371-382.

Raich, J. W., \& Schlesinger, W. H. (1992). The global carbon dioxide flux in soil respiration and its relationship to vegetation and climate. Tellus B, 44, 81-99.

Rayment, M. B., \& Jarvis, P. G. (2000). Temporal and spatial variation of soil $\mathrm{CO}_{2}$ efflux in a Canadian boreal forest. Soil Biology and Biochemistry, 32, 35-45.

Rustad, L. E., Huntington, T. G., \& Boone, R. D. (2000). Controls on soil respiration: implication for climatic change. Biogeochemistry, 48, 1-6.

Schimel, D. S. (1995). Terrestrial ecosystems and the carbon cycle. Global Change Biology, 1, 77-91.

Suh, S. U., Chun, Y. M., Chae, N. Y., Kim, J., Lim, J. H., Yokozawa, M., Lee, M. S., \& Lee, J. S. (2006). A chamber system with automatic opening and closing for continuously measuring soil respiration based on an open-flow dynamic method. Ecological Research, 21, 405-414.

Van Gestel, M., Ladd, J. N., \& Amato, M. (1991). Carbon and nitrogen mineralization from two soils of contrasting texture and micro-aggregate stability: influence of sequential fumigation, drying and storage. Soil Biology and Biochemistry, 23, 313-322

Wang, C. K., Yang, J. Y., \& Zhang, Q. Z. (2006). Soil respiration in six temperate forest in China. Global Change Biology, 12, 2103-2114.

Woodwell, G. M., Mackenzie, F. T., Houghton, R. A. Apps, M., Gorham, E, \& Davidson, E. (1998). Biotic feedbacks in the warming of the earth. Climatic Change, 40, 495-518.

Wu, Y., Liu, G., Fu, B., Liu, Z., \& Hu, H. (2006). Comparing soil $\mathrm{CO}_{2}$ emission in pine plantation and oak shurb: dynamic and correlations. Ecological Research, $21,840-848$.

Xu, M., \& Qi, Y. (2001). Spatial and seasonal variation of Q10 determined by soil respiration measurements at a Sierra Nevadan forest. Global Biogeochemical Cycles, 15, 687-696

Yun, K. S., Shin, S. H., Ha, K. J., Kitoh, A., \& Kusunoki, S. (2008). East Asian precipitation change in the global warming climate simulated by a $20-\mathrm{km}$ mesh AGCM. Asia-Pacific Journal of Atmospheric Sciences, 44, 233-247.

Yuste, J. C., Janssens, I. A., Carrara, A., Meiresonne, L., \& Ceulemans, R. (2003). Interactive effects of temperature and precipitation on soil respiration in a temperate maritime pine forest. Tree Physiology, 23, 1263-1270.

Zhou, X., Talley, M., \& Luo, Y. (2009). Biomass, litter, and soil respiration along a precipitation gradient in southern Great Plains, USA. Ecosystems, $12,1369-1380$

\section{Ready to submit your research? Choose BMC and benefit from:}

- fast, convenient online submission

- thorough peer review by experienced researchers in your field

- rapid publication on acceptance

- support for research data, including large and complex data types

- gold Open Access which fosters wider collaboration and increased citations

- maximum visibility for your research: over $100 \mathrm{M}$ website views per year

At BMC, research is always in progress.

Learn more biomedcentral.com/submissions 